Abstracta Iranica Abstranica

Revue bibliographique pour le domaine irano-aryen

Volume 34-35-36 | 2017

Comptes rendus des publications de 2011-2013

\title{
Judith Lerner, Nicholas Sims-Williams. Seals, Sealings and Tokens from Bactria to Gandhara (4th to 8th century CE)
}

\section{Rika Gyselen}

\section{(2) OpenEdition \\ Journals}

Édition électronique

URL : http://journals.openedition.org/abstractairanica/42335

DOI : 10.4000/abstractairanica.42335

ISSN : 1961-960X

Éditeur :

CNRS (UMR 7528 Mondes iraniens et indiens), Éditions de l'IFRI

Référence électronique

Rika Gyselen, « Judith Lerner, Nicholas Sims-Williams. Seals, Sealings and Tokens from Bactria to Gandhara (4th to 8th century CE) », Abstracta Iranica [En ligne], Volume 34-35-36 | 2017, document 50, mis en ligne le 30 juillet 2017, consulté le 02 octobre 2020. URL : http://journals.openedition.org/ abstractairanica/42335 ; DOI : https://doi.org/10.4000/abstractairanica.42335

Ce document a été généré automatiquement le 2 octobre 2020.

Tous droits réservés 


\title{
Judith Lerner, Nicholas Sims- Williams. Seals, Sealings and Tokens from Bactria to Gandhara (4th to 8th century $C E$ )
}

\author{
Rika Gyselen
}

\section{RÉFÉRENCE}

Judith Lerner, Nicholas Sims-Williams. Seals, Sealings and Tokens from Bactria to Gandhara (4th to 8th century CE). Wien, ÖAW, 2011, 222 p. (Veröffentlichungen der numismatischen Kommission, Band 52)

1 Publication d'objets inédits d'une collection privée censés provenir d'une vaste région qui s'étend de la Bactriane au Gandhara (carte p. 12). Beaucoup de sceaux sont inscrits dans des langues iraniennes : bactrien, moyen-perse et sogdien dont les légendes sont examinées par N. Sims-Williams (p. 179-204). La collection comporte aussi quelques sceaux et bulles sassanides. Mais comme la publication suit un ordre iconographique pour l'ensemble des objets, il faut chercher les objets sassanides dans les diverses rubriques iconographiques. L'objet le plus sensationnel est sans aucun doute le sceau du « roi des Huns, le grand Kūšān(-šah), l'afshiyan de Samarkand » (p. 72-74) dont d'autres empreintes, moins bien conservées, provenant des fouilles de Kafir Kala (Cazzoli / Cereti 2005), avaient déjà été publiées. 


\section{AUTEURS}

\section{RIKA GYSELEN}

CNRS, Mondes iranien et indien 